\title{
INTEGRATED QUALITY MANAGEMENT FOR MICE DESTINATIONS
}

\author{
Renata Pindžo $0^{1,2}$ \\ Igor Kovačević, \\ Bojan Zečević ${ }^{3}$
}

${ }^{1}$ Singidunum University, Faculty of

Economics, Finance and Administration, Belgrade, Serbia

${ }^{2}$ Ministry of Trade, Tourism and

Telecommunications, Serbia

${ }^{3}$ University of Belgrade,

Faculty of Economics,

Belgrade, Serbia
Correspondence:

Renata Pindžo

e-mail:

renata.pidndzo@mtt.gov.rs

\begin{abstract}
:
Quality is one of the key factors and determinants for destination competitiveness and is considered a decisive competitive instrument vital for the success of a destination. Destinations that are successful in meetings, incentives, conferences and events/exhibitions (MICE) industry understand the synergies of leisure tourism and business events, as well as their strong differences, especially having in mind how to market the product. MICE differs from leisure tourism in several aspects - motive and purpose of visit, decision making process, travel funding, period of traveling, supply stakeholders and requires a distinct strategy for attracting meetings. Destination quality must be considered as one of the priority performance parameters in the long-term vision and tourism policy at the national level. Quality in the meetings industry can be achieved through commitment of all stakeholders and joint activities directed towards "customer satisfaction". A convention bureau is a type of a destination management organization focused on managing meetings industry stakeholders in order to increase the volume of meetings at a destination. An important task of the convention bureau is to implement certain integrated quality management steps in order to have the standardized offer of the entire destination in the eyes of international clients. These steps include the activities such as developing partnership agreements with industry stakeholders, standardizing level of services and increasing the awareness of convention bureau activities to the public. This convention bureau enables it to raise the chance for the international client to choose a destination for some future event. Methodology is based on the case study analysis of the Serbia Convention Bureau that is implementing certain IQM steps in its operational and strategic activities.
\end{abstract}

Keywords:

quality management, destinations, MICE, convention bureau, customer satisfaction.

\section{INTRODUCTION}

Tourism is a global phenomenon, which represents one of the most important sectors of our time, an engine of economic growth, employment and investments (Unković \& Zečević, 2016), as well as general social progress and environmental sustainability (Petković \& Pindžo, 2012, p. 117). Furthermore, tourism is a major export sector in many countries. Over the past 60 years, tourism industry has recorded significant growth and diversification, proving to be one of the most growing economic sectors worldwide (Petković et al., 2015, p. 123). A lot of new tourism destinations have emerged alongside the traditional ones in Europe and North America. 
Tourism is a resilient industry (Cochrane, 2010), continuing to grow even during the period of economic crisis (Petković et al., 2016, p. 189). In 2015, the growth was observed in the number of international arrivals, which represents the sixth consecutive year of record growth with 1,184 million international tourist arrivals i.e. overnight visitors (from $6.6 \%$ in 2010 compared to 2009 to $4.4 \%$ in 2015 compared to 2014). The same trend continued in the first four months of 2016, when the number of international arrivals recorded growth of almost 5\% (UNWTO, 2016a). Modern tourism development is based on the destination development, permanent overall quality management, tourism offer and services improvement. According to the UNWTO (2016b), quality is one of the key factors and determinants for destination competitiveness, and a decisive competitive instrument vital for the success of a tourism destination. The UNWTO (2016b) defines quality as "the result of a process which implies the satisfaction of all tourism product and service needs, requirements and expectations of the consumer at an acceptable price, in conformity with mutually accepted contractual conditions and the implicit underlying factors such as safety and security, hygiene, accessibility, communication, infrastructure and public amenities and services. It also involves the aspects of ethics, transparency and respect towards the human, natural and cultural environment". Quality is achieved through a combination of better processes, better approaches, techniques and efforts of those who create products and services (Barković, 2011, pp. 192-193).

\section{INTEGRATED DESTINATION MANAGEMENT AS THE BASIS OF MODERN MICE TOURISM DEVELOPMENT}

The UNWTO Tourism Destination Management Think Tank in 2002 defined a (local) tourism destination as "a physical space where a tourist spends at least one overnight. It includes tourism products such as support services and attractions and tourist resources within one day's return travel time. It has physical and administrative boundaries defining its management, and images and perceptions defining its market competitiveness" (UNWTO, 2007, p. 1). In a broader sense, destinations are also countries, regions, human settlements and other areas that are typical with their high concentration of tourists, developed services and other tourism infrastructure, the result of which is a great long-term concentration of visitors (Pásková \& Zelenka, 2002). Buhalis (2000) defines a tourism destination with six components known as "6 As": attractions (cultural heritage and nature resources), amenities (tourism su- pra-structure mainly), ancillary services (general hard and soft infrastructure), accessibility, available (tourist) packages and activities. Middleton and Clarke (2001) state that attractions, amenities, accessibility, image and perception of a destination and the price are the elements that largely determine one destination. The UNWTO's (2007, pp. 1-2) standpoint is that the attractions, amenities, accessibility, image, price and human resources are the essential elements that severely affect the definition and determination of a destination. The practice of developed tourism countries points to the necessity of introduction of organized destination management (primarily through the establishment of destination management organization) as the basic precondition for raising the competitiveness of destinations as well as the introduction and development of integrated quality system. According to the European Commission (2000, p. 13), the concept of IQM was developed during the 1990s as a relatively new approach to tourism destination management, which represented a response to competitive pressures on both the supply and the demand side, a lack of the specified quality management in the tertiary sector and a complex nature of the overall quality management of tourism destinations due to various factors: the number of entities (stakeholders) involved in production and marketing the products and services in a destination and the problem of pinpointing and characterising tourists expectations. Furthermore, the European Commission (2000, p. 19) states that the IQM approach recommended for tourism destinations includes five main levels:

- partner identification (definition of the common project, determination of the lead partner, division of responsibilities among all partners),

- decision making about taking action (definition of strategy and polices referring to all the key elements such as human and natural resources, attractions, cultural heritage etc., all stakeholders and their planned roles and tasks, making the plan of activities),

- implementation of the agreed action (before, during and after the tourists visit),

- measurement of the effects of undertaken activities (determination and measurement of the main indicators) and

- evaluation and adjustments of the results (the basis for recommendation for all stakeholders from the public and private sector).

Destination and its understanding of the importance of the synergies as well as strong differences play the key role in MICE industry. According to Redor (2016), MICE tourism differs from leisure tourism (Fig. 1). The most 


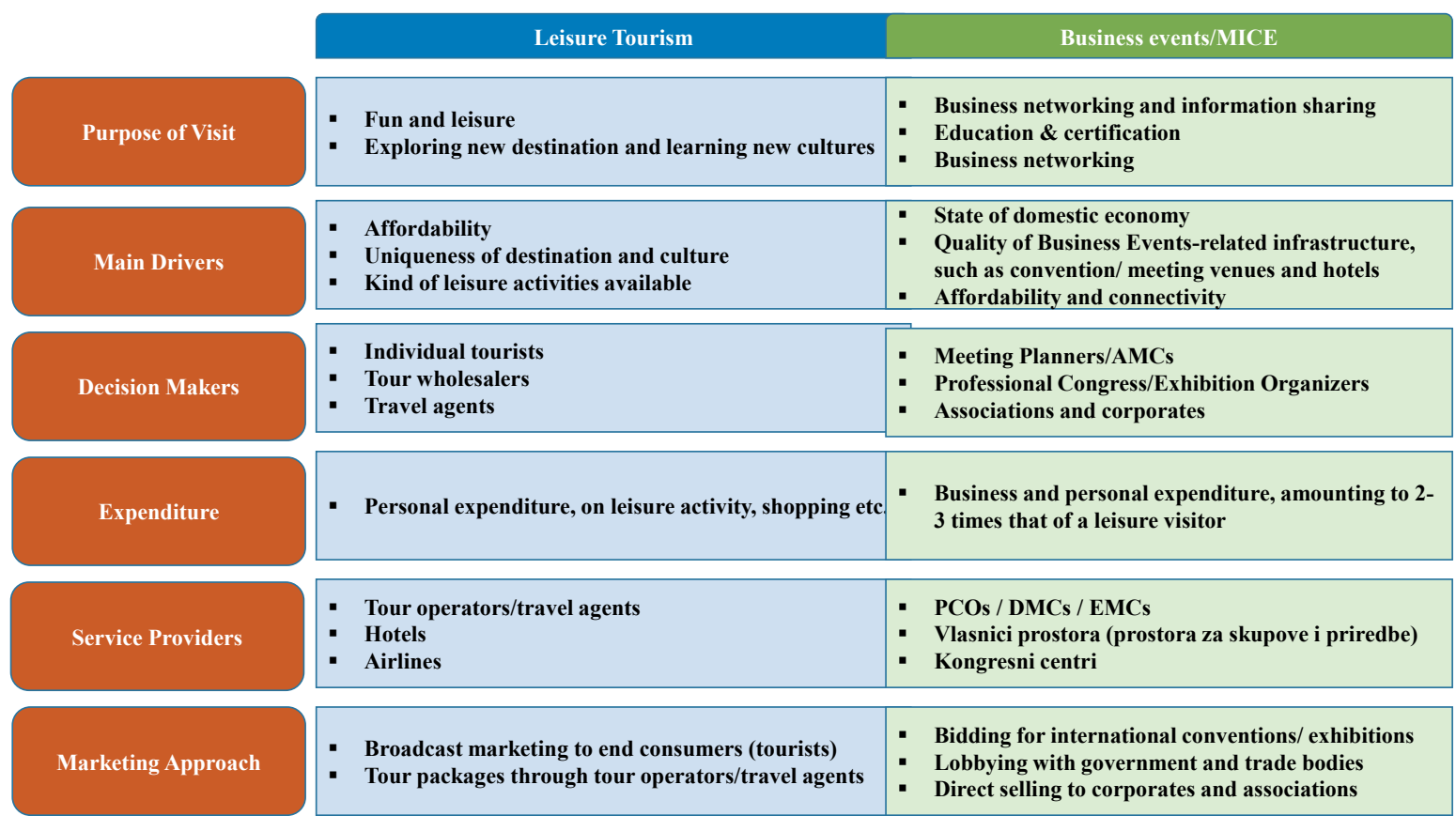

Figure 1. Leisure Tourism vs. MICE

Source: http://cf.cdn.unwto.org/sites/all/files/pdf/session_2_bruce_redor_quality_in_meetings_industry_tourism_france.pdf

significant difference is in market approach between leisure and business tourism: leisure tourism is characterised by promotional efforts directed towards end consumers (tourists) and selling of tourism arrangements through tour operators (organizers of travel packages) or travel agents. On the other hand, MICE industry includes joint lobbying of the public and private sectors, preparation of bids and direct sell to associations and corporations. Business events have direct microeconomic effects: increasing employment, directly generated revenues, as well as tax revenues for the public sector.

In order to become successful, a destination needs to be strategically oriented towards the development of MICE products, to coordinate all key stakeholders from the public and private sectors, to constantly improve congress and general infrastructure, as well as to implement the appropriate system of destination governance and management. Boundaries of MICE destinations do not necessarily coincide with the boundaries of destinations in terms of leisure tourism. Also, MICE destinations in the broader sense can refer not only to a city or town, but also to the resort, district, region, and ultimately the country. MICE destination is not exclusively related to the urban area. Bearing in mind the fact that MICE guests (business traveller, delegate), according to the estimates, daily spend on average 556 USD within a destination (according to ICCA on a world scale), which includes hotel accommodation and all expenditures outside the hotel, which is at least three times more than the consumption of "ordinary" tourists, it is clear why many countries are interested in development of this tourism product. Firstly, they are expecting a good financial result, significant profit for the local economy. However, MICE industry is much more. Based on the experience of developed MICE destinations, which are at the same time developed economies, it can be said that the wellthought strategy of MICE industry development, jointly defined by the public and private stakeholders, had a strong effect on the overall economic development of these countries. Through a strategically conceived lobbying, public sector and all relevant MICE stakeholders target business events and conferences from those sectors which have been identified as important for future development of the economy of these countries, in both association and corporate markets.

MICE industry is important because it represents an excellent basis for the so-called "invisible export" knowledge, technology, expertise and a platform for "knowledge-based society". The organization of business events and conferences is an opportunity for the local companies, professional associations, scientists and experts to come in contact with the companies that are leaders in certain branch or leading experts in a particular field in the world to expand their network of contacts and, finally, to establish business or scientific cooperation that will contribute to economic and social development. The organization of such events is a powerful lever in branding countries in business, academic, scientific and professional circles. On the other hand, momentum to the development of the MICE industry 
runs the whole spiral of investment activities, of which the most visible are investments in the hotel industry (hospitality industry). Consequently, we can talk about an increasing number of employees in tourism sector, increasing number of arrivals and overnights, increasing tourism inflow, increasing level of total consumption etc. In this regard, it is of great importance to establish the management structure in the entire MICE destination that will have the capacity to coordinate all stakeholders, since that is a precondition for successful development of MICE destination and achievement of the planned objectives. This role, having in mind experiences of already developed MICE destinations, is given to the convention bureau, whose task is coordination of activities, but also coordination of interests of all stakeholders from the public and private sectors on the destination. The convention bureau needs to define and follow the implementation of the quality standards that will comply with the existing internationally accepted quality standards in the MICE industry, which primarily relate to both the supply side (conference infrastructure, hotel, transport connections, the agency engaged in organizing the event, price range etc.) and the demand side (professional associations, corporate clients, number of delegates, the duration of the event, spending per delegate etc.). After the decline in the period 2000-2004, the conference industry achieved the largest growth worldwide since 2005, but despite the mentioned growth, there are certain trends that convention bureaus must take into account (UNWTO 2014; GCB 2013; own research based on ICCA Statistics reports 2000-2015): shorter duration of events; a smaller number of organized events; new destinations (e.g. such as those in China, Korea etc.) are becoming increasingly competitive to already established leaders in this area; the issue of safety and security is a major challenge in the selection process of a MICE destination as a result of the growing threat of terrorism in the world (Campiranon, 2006).

Integrated quality management (IQM) is an integral part of the destination management (Zabkar et al., 2010) and we can say it is also one of the key success factors of MICE destinations. Consumer satisfaction is in the focus of this system. The image of the entire destination, consumers' expectations (Armstrong et al., 1997), and the perceived quality of destination attributes (Cole et al., 2006) and services (Lee et al., 2000) create the perceived value that is the basis for consumer satisfaction, which should result in loyalty creation. In addition to the standard characteristics of IQM in developing as well as developed MICE destinations, an integrated system of quality management for MICE industry is developed. IQM involves the management of defined quality standards, both on the supply and the demand side. Quality standards are usually defined by the global MICE industry associations. In their definition, a consensus between the leading players is crucial because only the standards defined "inside" should enable sustainable development for the industry, but at the same time, they should be defined flexibly in order to be eligible for diversified MICE industry (organizers of events of different sizes, different number of participants etc.) and focused on measurable results. The standards are usually related to the definition of the quality required for determination of the meeting venue, technological equipment, accommodation, transport connections, the quality of the place/destination, environmental issues, training and education of personnel, professional materials etc. Implementation of standards should be on a voluntary basis. Quality standards must include every element and every phase of organization. IQM represents a guarantee of a certain level of quality. Convention bureau is precisely the mechanism that is acting as the coordinator in the implementation of IQM at the destination.

The good examples are: Best City Global Alliance (world's first convention bureau association) and Thailand Convention and Exhibition Bureau. The Best City Global Alliance represents the capitals or leading cities of the following countries: Germany, Colombia, South Africa, Denmark, UAE, Scotland, the USA, Australia, Singapore, Japan and Canada. The association was founded with the aim to advance and homogenize the quality of services delivered to the clients, thus adding value to the competitiveness of the mentioned convention destinations. Those standards include training of employees, internal/external audits of service standards, supplier control process, management of client requirements, events promotional support, destination expertise, bid assistance, convention planning, on-site event servicing and post-event evaluation. Thailand Convention and Exhibition Bureau (TCEB) adopted a set of quality standards of destination management (ISO 2200: for food management system, ISO 50001: for energy management system, National skills: for MICE industry, TISI 22300: for MICE security management system, ISO 20121: for event management sustainability system, Thailand' MICE hotel standards, ISO 9001: for quality management system). TCEB carries out the procedure of certification of those subjects who voluntarily meet these standards, and consequently, wish to provide services in the MICE industry. Due to the results TCEB achieved by implementing these standards, all countries of the Association of Southeast Asian Nations (ASEAN) have accepted them. 


\section{THE CASE STUDY: SERBIA CONVENTION BUREAU}

Serbia Convention Bureau (the SCB) was established almost 10 years ago. The SCB started its first official activities during May 2007, by exhibiting at the IMEX, The Meetings Industry Tradeshow. It was formed as a sector within the National Tourism Organization of Serbia (NTOS), and is still keeping this form. The establishment of SCB was foreseen by the Strategy for Tourism Development 2005-2015, since the MICE was declared as the "quick win" product for Serbia, mainly due to the inherited congress infrastructure, which was (more or less) ready for international sale and promotions. It was supported from the very beginning by the MICE industry stakeholders - congress centres, hotels and other providers that have grown together with the SCB in the last 10 years. In 2007, when the SCB was established, Serbia was ranked the $72^{\text {nd }}$ on the global ranking of destinations attracting international association meetings, with 21 international association meetings held in Serbia. Three years later, Serbia joined the top 50 international destinations and moved to the $47^{\text {th }}$ position. In 2015, Serbia reached the $43^{\text {rd }}$ place in the world, and is still maintaining that position.

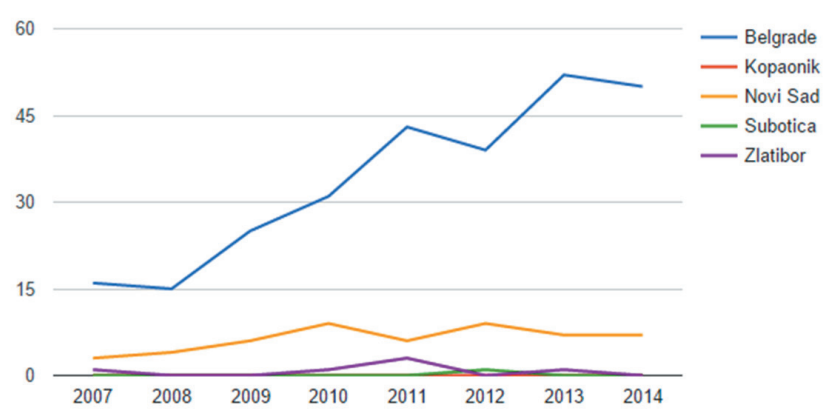

Figure 2. Number of international meetings in Serbia Source: ICCA Statistics Reports 2007-2015

The total number of meetings in 2014 more than tripled, thus making Serbia one of the fastest growing MICE destinations in the world. The total number of delegates at international meetings in Serbia increased from 3555 in 2007 to 11926 in 2014, out of which almost $70 \%$ attended meetings in Belgrade. In 2014, Belgrade assumed $50^{\text {th }}$ position in the world and $23^{\text {rd }}$ in Europe with 50 international meetings (business events). There are two internal, destination-related reasons for this intensive growth, besides external factors not under the destination control.

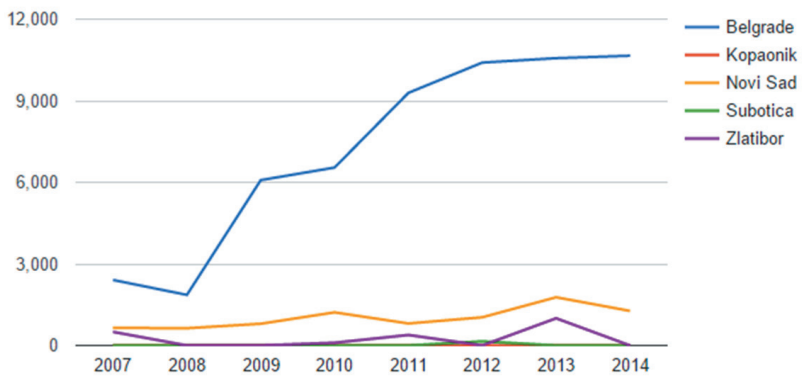

Figure 3. Number of delegates at international meetings in Serbia

Source: ICCA Statistics Reports 2007-2015

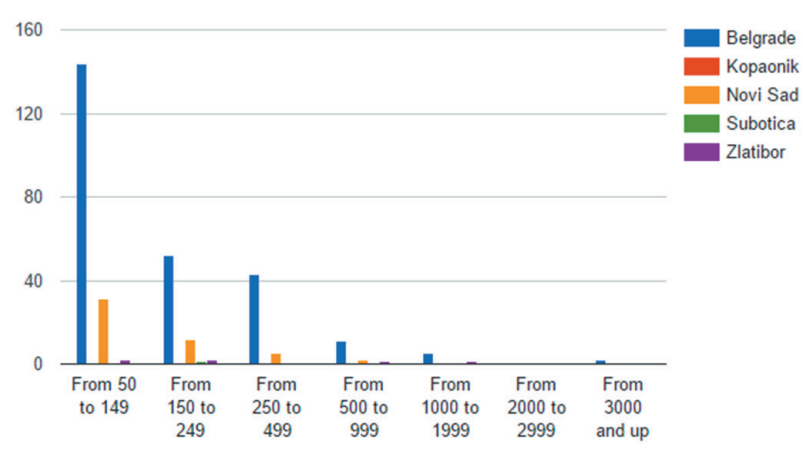

Figure 4. Number of events by category

"size of the event"

Source: ICCA Statistics Reports 2007-2015

High growth rates are due to the low starting position of Serbia as a MICE destination that has undergone certain socio-economic challenges. However, low staring position means that there is a small number of international meetings, limited number of service providers and the lack of understanding of the importance of the MICE industry for Serbia. In such a situation, growth usually does not just happen. It has to be driven, and establishment of the SCB was the first reason for the success of Serbia as a MICE destination. It brought better international promotion and proper monitoring of the market trends. The second reason for the progress is based on the SCB's implementation of IQM activities. The foremost activity that adds value to the total quality of Serbian meetings industry product is the partnership relationship between the SCB and the MICE industry stakeholders. Having in mind that the SCB is part of the National Tourism Organization of Serbia, and therefore not entirely eligible for the membership-based cooperation with the industry, the partnership model has been implemented. One of the most important rules that the SCB follows is the "golden rule" of treating equally all industry partners. According to the SCB's web site 
(www.scb.travel), there are 73 industry partners classified into congress centres, hotels, agencies and other providers. Industry is influencing the SCB activities through the Industry Board and Expat Advisory. These bodies are informal and voluntary, and their decisions are not binding but rather advisory. However, they are of crucial importance.

Through partnership agreements, the SCB has managed to increase total capacities offered to international clients, since the SCB started to coordinate all activities and marketing focused on foreign clients. Before the establishment of the SCB, all sales and marketing activities on the MICE industry market were limited to individual efforts. The partnership has been used as a joint platform for better and more effective sales-oriented communication directly towards international clients. In order to sustain the growth of the MICE tourism, the SCB needed to implement additional measures of IQM. That is why the SCB initiated the process of industry standardization. This process allows partners from the industry to build-up their capacities according to the standards recommended by the international associations such as International Congress and Convention Association (ICCA), Meetings Professionals Internationals (MPI), International Association of Professional Congress Organizers (IAPCO) and Convention Industry Council (CIC). It was initiated at the beginning of 2016, and the full implementation is expected by the end of 2017. One of the most important aspects is to make clear differentiation between travel intermediaries (they are all still registered as travel agencies): destination management companies (DMC), professional congress organizer (PCO), event management company (EMC) and the travel agency per se (that was regulated by the amendments to the Tourism Law, October 2015). This clarification will also help the clients to understand the scope of the work of the chosen agency, and will help agencies to specialize themselves. Furthermore, the hotels will be classified into congress hotels, hotels with congress capacities and additional hotels. The standards will also be coordinated with the ministry in charge of tourism, since there is the need to make the MICE tourism and industry more visible among the government decision makers.

The final step of the IQM implementation by the SCB in Serbia is related to developing better visibility of the SCB and Serbian MICE industry. For this reason, the SCB has initiated the Ambassador program - the initiative that gathers all influential academicians, professors, scientists, and professionals in their field - in order to communicate wider values and benefits that international congresses and events are bringing to Serbia, not just those of increased spending, overnights and collected taxes. Those wider values are gathered around the idea of knowledge-based societies, promotion of knowledge, expertise, science and research. Working together with the ambassadors on bringing international events, the SCB is setting up a platform for promotion of domestic know-how and expertise to the world, bringing international knowledge and expertise to Serbia, and creating opportunity for Serbia to be internationally recognised as the centre of excellence in the certain field.

All of the mentioned activities need to be supported by sufficient resources - financial, human and knowhow. At the moment, only 3 employees are working in the SCB, which represents $10 \%$ of all employees in NTOS. The budget of the SCB is $5-7 \%$ of NTOS's budget. Having in mind what the SCB and Serbia have achieved in the field of MICE tourism, the implemented quality management steps can be recognized as one of the key success factors. According to the analysis of the activities of the SCB in 2015, $80 \%$ of the annual budget was used to cover the costs of organization of two major trade shows (IMEX, IBTM). The remaining 20\% is invested in the following undertakings: site inspection, familiarization tours and bidding for international events. Therefore, it is important to understand that the limited resources are effectively and strategically used, resulting in direct MICE business volume of over 2.5 million euro for Serbia.

Also, having in mind the standards defined by the Best Cities Alliance, the Serbia Convention Bureau has the following standards fulfilled: 1) staff training: although there are three employees, and that the Bureau suffered employee generation change, we can say that all employees have necessary knowledge and are involved in the industry hands-on trainings; 2) supplier control process: although meetings product is not totally under control of any the SCB or DMO in the world, Serbia Convention Bureau is working hard on supply side coordination, and this is done through industry board meetings, annual meetings of the industry, and through regular 1-on-1 meetings with service providers. The principal idea is to coordinate sales and marketing efforts, so that the image consistency can be achieved; 3) management of client requirements: the SCB is dealing with this activity daily, through responding to client requirements, but also through proactive search of new prospective leads and clients; 4) promotional support to events: the SCB provides support to local associations and local corporations in promotion of their international event in Serbia in order to maintain it, or to increase the number of delegates in Serbia; 5) destination expertise: the SCB can be categorized as a destination 
expert, having in mind the relationship with all partners, but also networking within the attractions, experiences and others; 6) bid assistance: the SCB is the leading process of bidding for international events, and it also provides support to local PCO, congress centres and local societies in this process. Services that are currently not being done by the SCB are: convention planning, on-site event servicing and post - event evaluation. The reason for that are limited resources, both human and financial.

\section{LIMITATIONS}

Most conclusions concerning Serbia's performances are based on the International Convention and Congress Association (ICCA) data, which relies solely on the figures related to the events organised by international associations. This means that only a portion of the MICE industry volume is captured. There are several reasons for this; the most important is that a number of corporate, government and other forms of meetings are not publicly reported.

\section{CONCLUSION}

Integrated quality management has a broader context than "product and service quality", and it brings a comprehensive set of benefits to the destination, businesses and the local community. IQM is vital for the success of one tourism destination in modern tourism market. This is especially important for tourism destinations that are at developmental stage, as is the case with Serbia. Bearing in mind the benefits and importance of MICE tourism for destinations, systematic approach to quality destination management is an imperative. The Serbia Convention Bureau can be classified as the successful MICE tourism related destination management organization on a national level. A successful DMO in MICE sector needs to follow and implement quality standards suggested by industry associations. As shown in the Serbia case study, the standards of successful convention bureau include: employee capacity building, supplier cooperation, client relationship management, congress promotional support and bidding process. Product development is a key ingredient for all these standards. The current level of the SCB's activities is on the maximum having in mind the human and financial limitations. For further development of Serbia as a MICE destination, certain challenges need to be tackled internally. First, investment in the promotion of Serbia as a MICE destination is relatively low (only $5-7 \%$ of entire tourism promotion budget). For better results, the MICE budget should not be smaller than $12-15 \%$. Secondly, increasing the number of employees would increase the level of operations, leading to a greater number of international events. The Serbia Convention Bureau should have at least 5 full time employees. Externally, the biggest challenge is renovation of the leading congress capacity and major congress centre (The Sava Centre). It requires urgent reconstruction, as well as a completely new management system.

\section{REFERENCES}

Armstrong, R.W., Mok, C., Go, F. M., \& Chan, A. (1997). The importance of cross-cultural expectations in the measurement of service quality perceptions in the hotel industry. International Journal of Hospitality Management, 16(2), 181-190. doi:10.1016/ S0278-4319(97)00004-2

Barković, D. (2011). Uvod u operacijski management. Osijek: Ekonomski fakultet u Osijeku.

Buhalis, D. (2000). Marketing the competitive destination of the future. Tourism Management, 21(1), 97-116. doi:10.1016/S0261-5177(99)00095-3

Campiranon, K. (2006). Understanding crisis vulnerability of the MICE sector: A case study of Thailand. In Global Events Congress (pp. 58-65).

Cochrane, J. (2010). The sphere of tourism resilience. Tourism Recreation Research, 35(2), 173-185.

Cole, S.T., \& Illum, S. F. (2006). Examining the mediating role of festival visitors' satisfaction in the relationship between service quality and behavioural intentions. Journal of Vacation Marketing, 12(2), 160-173. doi:10.1177/1356766706062156, p.

European Commission. (2000). Towards quality urban tourism: Integrated Quality Management (IQM) of Urban Destinations. Retrieved August 30, 2016 from http://ec.europa.eu/DocsRoom/documents/3634/ attachments/1/translations/en/.../pdf

German Convention Bureau. (2013). Meetings and Conventions 2030: A Study of Megatrends Shaping Our Industry. Retrieved August 28, 2016 from http://www.imexexhibitions.com/media/350647/ GCB-Zukunftsstudie2013_Zusammenf_E_LAY5.pdf

Government of Serbia Strategies. (2006). Strategy for Tourism Development of the Republic of Serbia 2005-2015. Retrieved August 29, 2016 from http:// www.gs.gov.rs/english/strategije-vs.html

International Congress and Convention Association (2015). Statistics Reports 2000-2015. Retrieved August 28, 2016 from www.iccaworld.com/dcps/doc. cfm?docid $=1789$

Lee, H., Lee, Y., \& Yoo, D. (2000). The Determinants of Perceived Service Quality and Its Relationship with Satisfaction. Journal of Services Marketing, 14(3), 217-231. doi:10.1108/08876040010327220 
Middleton, V.T.C., \& Clarke, J. R., (2001). Marketing in Travel and Tourism. Oxford: Butterworth Heinemann.

Paskova, M., \& Zelenka, J. (2002). Výkladovýslovnik cestovniho ruchu. Prague: MMR. p. 448.

Petković, G., Lovreta, S., Pindžo, R., \& Pešić, S. (2016).Evaluating the Concentration in Serbian Tourism and FMCG Retail Sector. Ekonomika preduzeća, 64(1-2), 187- 198.

Petković, G., Lovreta, S., \& Pindžo, R. (2015). New Strategic Cycle in the Serbian Trade and Tourism Development. Ekonomika preduzeća,.115-130.

Petković, G., \& Pindžo R. (2012). Tourism and New Economic Challenges. Ekonomika preduzeća, p. 117-126.

Redor, B. (2016). IQM for MICE Destinations: A Key to Success, a presentation from the UNWTO International Conference on Integrated Quality Management in Tourism Destinations: A Key to Competitiveness. Retrieved August 29, 2016 from http://cf.cdn.unwto. org/sites/all/files/pdf/session_2_bruce_redor_quality_in_meetings_industry_tourism_france.pdf

Terzibasoglu, E. (2016). Summary/Conclusions from the UNWTO International Conference on Integrated Quality Management in Tourism Destinations: A Key to Competitiveness. Retrieved September 2, http://cf.cdn.unwto.org/sites/all/files/pdf/technical_conclusions.pdf
Unković, S., \& Zečević, B. (2016). Ekonomika turizma. Beograd: Ekonomski fakultet.

UNWTO. (2007). A Practical Guide to Tourism Destination Management. Madrid: UNWTO.

UNWTO. (2014). Global Report on the Meetings Industry. Retrieved August 21, 2016 from http://www.imexexhibitions.com/media/350548/ UNWTO_meetingsindustry_am_report\%20(2).pdf

UNWTO. (2016a). World Tourism Barometer. Retrieved August 22, 2016 from http://cf.cdn.unwto.org/sites/ all/files/pdf/unwto_barom16_04_july_excerpt_pdf

Vajčnerová, J., \& Ryglová, Š.K. (2012). Using the Principal Component Analysis for Evaluating the Quality of a Tourist Destination. Acta Universitatis Agriculturae et Sivilculturae Mendelianae Brunensis, 59(2), 449-458.

Zabkar, V., Makovec Barencic., M., \& Dmitrovic, T. (2010). Modelling perceived quality, visitor satisfaction and behavioural intentions at the destination level. Tourism Management, 31(4), 537-546. doi: 10.1016/j.tourman.2009.06.005 